\title{
Microbiology Specimen Condition
}

National Cancer Institute

\section{Source}

National Cancer Institute. Microbiology Specimen Condition. NCI Thesaurus. Code C87901.

A characteristic that refers to the physical and organoleptic state of a microbiology specimen. 